\title{
The Hedgehog Signalling Pathway in the Gastrointestinal Tract: Implications for Development, Homeostasis, and Disease
}

\author{
CHARLIE LEES, ${ }^{*}{ }^{\ddagger}$ SARAH HOWIE, ${ }^{\ddagger}$ R. BALFOUR SARTOR, ${ }^{\S}$ and JACK SATSANGI* \\ *Gastrointestinal Unit, School of Molecular and Clinical Medicine, Western General Hospital, University of Edinburgh, Edinburgh; \\ ${ }^{\dagger}$ Immunobiology Group, Centre of Inflammation Research, University of Edinburgh, Edinburgh, United Kingdom; ${ }^{\S}$ Division of Gastroenterology \\ and Hepatology, The University of North Carolina, Chapel Hill, North Carolina
}

The hedgehog signalling pathway is critical to normal mammalian gastrointestinal development. Through epithelial-mesenchymal interactions, hedgehog signalling ensures appropriate axial patterning of the embryonic gut. Congenital abnormalities, including malrotations, anorectal malformations, and tracheoesophageal fistula are associated with germ-line mutations/deletion of genes encoding hedgehog signalling components in man and present in genetically engineered animal models. In adults, there is evidence that the pathway plays a role in maintaining stem cell populations in the stomach and directing epithelial cell differentiation in the intestine. Recent data implicate hedgehog signalling in the formation and maintenance of a number of malignancies, including those of the upper gastrointestinal (GI) tract and pancreas, in which abrogation of the pathway offers a novel therapeutic approach in animal models. Most recently, evidence in vitro indicates that there is a recapitulation of embryonic hedgehog signalling in acute epithelial injury and chronic inflammation, a finding with key implications for inflammatory disorders of the intestine, such as inflammatory bowel diseases. This pathway may provide an important link between chronic inflammation and cancer. We summarize the available evidence demonstrating that this developmental pathway has continuing roles in adult homeostasis and is dysregulated in malignancy and inflammation of the gastrointestinal tract.

I $\mathrm{t}$ is becoming increasingly clear that signalling path1 ways important in prenatal development continue to have vital roles in adult life by directing differentiation, determining cell fate, maintaining stem cell niches, and coordinating appropriate cellular responses to injury. These pathways influence many disease processes; in some situations, the normal critical balance of signalling components is upset by inherited variants, whereas in others, ligand-driven up-regulation of signalling is a sufficient driving force. The explosion of research into these signalling pathways has revealed a multitude of novel therapeutic targets.

This review focuses on the hedgehog $(\mathrm{Hh})$ signalling pathway and highlights how current insights into its role in GI development have greatly increased our understanding of adult health and disease. This pathway is responsible for several relatively common congenital malformations such as tracheoesophageal fistula and anorectal malformations. Hh signalling is strongly implicated in maintaining stem cell niches in the stomach and directing enterocyte differentiation in the colon. Furthermore, it plays critical roles both in the formation and in the maintenance of GI malignancies, including pancreatic adenocarcinomas, cholangiocarcinoma, and colorectal cancer. Based on the increasing knowledge of how $\mathrm{Hh}$ interacts with the immune system, on its involvement in various non-GI inflammatory disorders, and on recently published data, ${ }^{1}$ we hypothesize links between dysregulation of this pathway and inflammatory disorders of the GI tract, in particular the inflammatory bowel diseases and associated malignancies.

\section{Hh Signalling}

The Hh signalling pathway was originally described in the development of Drosophila melanogaster as a segment polarity gene required for embryonic patterning. ${ }^{2}$ The genes involved in Drosophila are Hedgehog (Hb), Patched (Ptc), Smoothened (Smo), Hedgehog-interacting protein (HIP1), Costal-2 (Cos-2), Fused (Fu), Suppressor of Fused $(S u(F u))$, and Cubitus interruptus $(C i)$. The pathway components demonstrate high interspecies conservation. ${ }^{3}$

\footnotetext{
Abbreviations used in this paper: Dhh, Desert hedgehog; EA/TEF, esophageal atresia/tracheo-esophageal fistula; Hh, hedgehog; HIP, hedgehog-interacting protein; Ihh, Indian hedgehog; N-Hhp, processed hedgehog; Ptc, patched; Smo, smoothened; Shh, Sonic hedgehog. (C) 2005 by the American Gastroenterological Association 0016-5085/05/ $\$ 30.00$ doi:10.1053/j.gastro.2005.05.010
} 

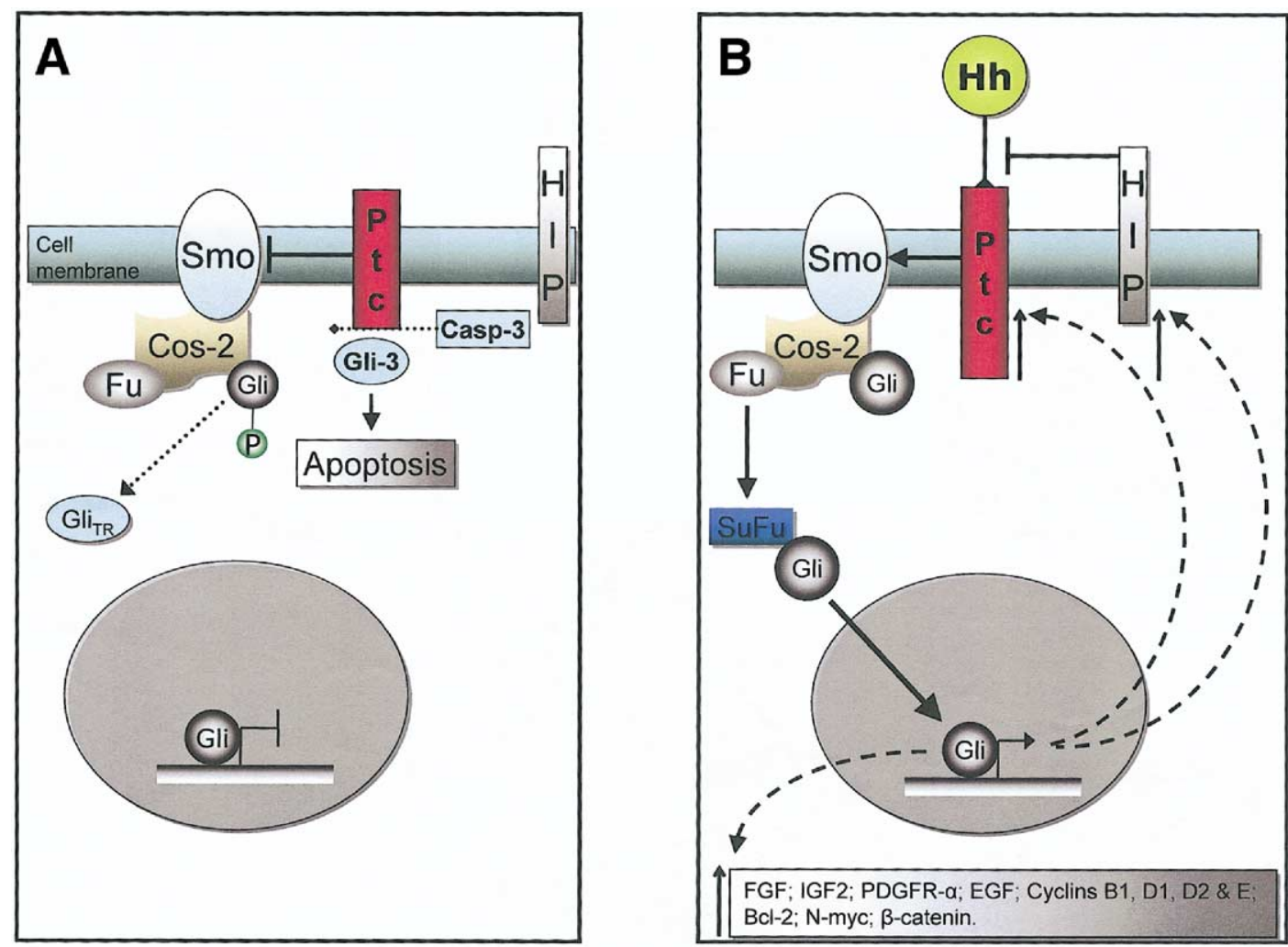

Figure 1. Hh signalling in mammalian cells. In the absence of Hh protein $(A)$, the 12-transmembrane domain receptor Ptc exerts an inhibitory effect on Smo, a 7-pass transmembrane protein with homology to G-protein-coupled receptors. Smo, in complex with Cos-2, prevents nuclear availability of the full Gli product. ${ }^{116}$ This occurs by a combination of microtubule binding of the complex and proteolysis to a truncated Gli (Gli ${ }_{T R}$ ). Furthermore, when Ptc is unoccupied by $\mathrm{Hh}$, it is suggested that caspase-3 (casp-3) cleavage of its intra-cellular portion exposes a receptor region that transduces an apoptotic signal via Gli-3. In the presence of Hh ligand-binding $(B)$, the inhibitory action of Ptc on Smo is released. The full Gli product is now stabilized and transferred to the nucleus. This process is likely mediated in part by conformational change in the Cos-2/Gli/Fu complex and also by interaction of Gli with a phosphorylated Su (Fu). Once in the nucleus, the full Gli product binds to and up-regulates transcriptional targets, including Ptc and another Hh-binding protein, HIP. In this manner, excess Hh is sequestered, and control is exerted on the pathway.

There are 3 vertebrate homologues of Hh: Sonic hedgehog (Shb), Indian hedgehog (Ihb), and Desert hedgehog (Dhb). These demonstrate different, but frequently overlapping, expression patterns. They have remarkably similar biological properties, albeit with differing potency $(S h h>I h b>D h b)$ noted in some, but not all, experimental assays. ${ }^{4}$ Increasing evidence implicates accessory molecules in mediating $\mathrm{Hh}$ activity, ${ }^{5-7}$ and there may be a role for these in modulating this potency. Most research has centred on Shh. The 2 homologues for patched, patched-1 (Ptc-1) and patched-2 (Ptc-2), both bind vertebrate Hh with similar affinity. Ptc-1 is found in target cells and up-regulated by $\mathrm{Hh}$ signalling. ${ }^{8} \mathrm{Ptc}-2$, although little studied, is coexpressed with $\mathrm{Hh}$ and does not depend on it for transcription.9,10 The 3 homologues for Ci, Gli-1, Gli-2, and Gli-3, are responsible for many of the refined complexities and intricacies observed in mammalian Hh signalling.

$\mathrm{Hh}$ is synthesised as a 45 -kilodalton precursor protein that undergoes autoproteolysis. ${ }^{11-13}$ The active $\mathrm{N}$-termi- nal signalling domain $(\mathrm{N}-\mathrm{Hh})$ is released once the catalytic C-terminal portion has been removed and a cholesterol molecule has been added (N-Hhp). ${ }^{14}$ With the addition of cholesterol, a modification to N-Hhp that is unique among signalling molecules, $\mathrm{N}-\mathrm{Hhp}$ is rendered hydrophobic and thus able to bind to the cell membrane at which it mediates local signals. In an independent step, the $\mathrm{N}$-terminus can be further modified by palmitoylation, increasing hydrophobicity. ${ }^{15}$ Furthermore, NHhp, once released from the cell via the transmembrane protein Dispatched, ${ }^{16}$ functions to provide a long-range, paracrine signal to target cells. ${ }^{17}$ At the present time, the mechanisms involved in short-range and long-range signalling remain contentious and under investigation. The transduction of the Hh signal has many interesting and unique facets (Figure 1) that share some similarities with Wnt signalling. ${ }^{18-20}$

As with most cell signalling pathways, regulatory mechanisms exist for $\mathrm{Hh}$ signalling. Hh activity induces further expression of its transmembrane receptor Ptc, 
thus simultaneously initiating signalling while restricting the range of movement by sequestering Hh protein. Another cell-surface protein that binds to and sequesters $\mathrm{Hh}$, HIP $1,21,22$ is also up-regulated by pathway activation, thus serving to down-regulate $\mathrm{Hh}$ activity. The phenotype of HIP knockout $\left(H I P^{-1-}\right)$ mice is consistent with increased Hh signalling. ${ }^{23}$ Megalin, a low-density lipoprotein (LDL) receptor-related protein, is also active on the cell surface and controls the endocytic uptake of the $\mathrm{Hh}$ protein by acting as a direct binding partner in vitro, although little is known of its function in vivo. ${ }^{24,25}$ The regulation of $\mathrm{Hh}$ signalling at different levels indicates that tight control is crucial to its proper function, analogous to regulation of other key signalling pathways,

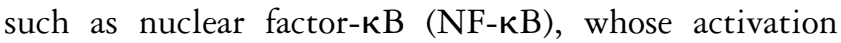
induces inhibitory molecules (I $\mathrm{B} \alpha \alpha$ and others). ${ }^{26}$

\section{Hh Signalling in Development}

\section{Hh Signalling Is Critical in the Embryonic Development of the GI System}

The gut develops from a primitive endodermal tube that gives rise to the pharynx, esophagus, stomach, small intestine, and colon. Endodermal buds grow into mesenchyme closely associated with the tube and form the liver and pancreas. The key molecular pathways involved are the $\mathrm{Hh}$, bone morphogenetic protein (BMP), Notch, and Wnt/ $\beta$-catenin signalling pathways; the Hox and Sox transcription factors; and the Eph receptor/ephrin ligand signalling system. ${ }^{27}$ Patterned gene expression within the endoderm and surrounding mesoderm regulates the morphogenesis, differentiation, and boundaries of these organ primordia. ${ }^{28}$ The cross talk generated between endoderm and mesoderm is critical to this process and later establishes radial patterning within the developing digestive tract. Hh signals are a vital component of this cross talk and thus essential to the normal patterning of the GI track along anterior-posterior (A-P), dorsal-ventral (D-V), and radial axes. ${ }^{29}$ In the animal models studied, high levels of the Hh receptor Ptc-1 in the mesenchyme allow for processing of the signals generated endodermally. ${ }^{30-34}$ Paracrine signalling in the late gestational (E18.5), murine small intestine has been elegantly demonstrated after careful separation of these components. ${ }^{35}$ Shh and Ihh are present in epithelial cells, with Ptc and Gli1-3 mRNA detected almost exclusively in the mesenchymal compartment. Hh signals can, however, also act cell autonomously as they do in developing and adult pancreatic islets in which Ihh and Ptc-1 colocalize. ${ }^{36,37}$ Of great relevance, manipulation/interruption of $\mathrm{Hh}$ components in animal models bears a close resemblance to many human con- genital malformations arising from abnormalities in foreand hindgut development.

Developmental patterning by $\mathrm{Hh}$ in Drosophila is largely dependent on concentration gradients. ${ }^{38}$ In the mammalian ventral neural tube, the morphogenic gradients of Shh setup in the notochord and floor plate determine the differentiation of progenitors into several different cell types (reviewed in McMahon et al, 200339). In the developing gut, the overlap in expression of $2 \mathrm{Hh}$ homologues, Shh and Ihh, may serve to generate greater variation in concentration gradients. Additionally, the different phenotypes of the knockout mice ( $S h b^{-1-}$ and $I h b^{-1-}$ ) suggest that the 2 homologues have different functions during intestinal development.

Hh proteins are highly expressed in the murine embryonic gut and decrease after birth. ${ }^{34}$ Shh and Ihh are expressed in mouse gut endoderm in overlapping patterns. From day 8.5 of gestation (E8.5), the proteins are present in 2 ventrolateral strips in gut endoderm. ${ }^{40}$ This is noted first in the caudal hindgut, followed by foregut pocket and then hindgut. Shh is down-regulated in 2 critical areas: in the prospective pancreatic endoderm to allow normal pancreatic development and along the small intestine, possibly to allow normal intestinal epithelial differentiation. ${ }^{41}$ By E18.5, there is expression of Shh and Ihh in the glandular stomach, small intestine, and colon. Shh is mostly restricted to colonic crypts at this time.

\section{Shh, Ihh, and Gli Knockout Mice}

$S h b^{-1-}$ and $I h b^{-1-}$ mice die peri- or immediately postnatally. ${ }^{31}$ Both mutant embryos (examined at E18.5) show significant GI defects, both common (smaller, overtly malrotated GI tracts) and distinct (Table 1). There are no data reporting any such defects in $D h b^{-1-}$ mice (males are viable, but sterile because of defective spermatogenesis ${ }^{42}$ ).

The $S h b^{-1-}$ embryo displays a hyperplastic stomach epithelium with some intestinal transformation of the glandular epithelium. Overgrown villi in the duodenum are seen to cause an occlusion similar to duodenal stenosis in humans. On dissection, the colon terminates in a blind dilatation leading to imperforate anus. ${ }^{31}$ Furthermore, Gli-2 $^{-1-}$ and Gli-3 $^{-1-}$ mice exhibit, respectively, imperforate anus with rectourethral fistula and anal stenosis. ${ }^{43}$ Mice with a truncated Gli-3 $\left(\right.$ Gli-3 $\left.^{\Delta 699 / \Delta 699}\right)$, resembling the aberrant transcription factor in PallisterHall syndrome, display imperforate anus, reduced size of small intestinal villi, dilated intestine, and thin-walled colons. ${ }^{44}$ Gli-1 $1^{-1-} / G l i-2^{-1-}$ double knockouts have a persistent cloaca, whereas the mixed homo-heterozygous mutants show interim changes consistent with a gene 
Table 1. Phenotypes of the Various Hedgehog Component Knockout and Transgenic Mice

\begin{tabular}{|c|c|c|}
\hline \multirow{2}{*}{$\begin{array}{l}\text { Genotype } \\
\text { (References) }\end{array}$} & \multicolumn{2}{|r|}{ Phenotype } \\
\hline & Lethality & GI defects \\
\hline $\operatorname{Shh}^{-1-}(30,31,36)$ & Perinatal death & $\begin{array}{l}\text { General: Body size } 30 \% \text { of wild type; small, malrotated Gl tract } \\
\text { Foregut: EA/TEF with severe lung hypoplasia. } \\
\text { Stomach: Hyperplastic gastric epithelium, increased number of glucagon-positive } \\
\text { cells } \\
\text { Small intestine: Decreased smooth muscle thickness; overgrowth of duodenal villi } \\
\text { Pancreas: Increased size and endocrine cell number; annular pancreas } \\
\text { Lower GI: Imperforate anus } \\
\text { ENS: Abnormal differentiation of neurons under epithelium, with migration into } \\
\quad \text { villi }\end{array}$ \\
\hline$I h h^{-/-}(31,36)$ & Perinatal death & $\begin{array}{l}\text { General: Body size } 67 \% \text { of wild type; small, malrotated Gl tract } \\
\text { Pancreas: Annular pancreas } \\
\text { Lower GI: Macroscopically dilated segments resemble Hirschprung's } \\
\text { ENS: Microscopic absence of neurons, corresponding to dilated segments of SI } \\
\quad \text { and colon }\end{array}$ \\
\hline$S h h^{-/-} / I h h^{-/-}(31)$ & Die: E8.0 & \\
\hline $\mid p f l / P d x 1-S h h(59)$ & Viable & $\begin{array}{l}\text { Pancreas: Disrupted morphogenesis; pancreatic mesoderm develops into } \\
\text { intestinal mesenchyme }\end{array}$ \\
\hline Ptc-1-1- $(36,123)$ & Die: E9-10.5 & Pancreas: Pdx1, glucagon absent from pancreas at E9.5 \\
\hline Ptc-1 $1^{+/-}(36)$ & Viable & Pancreas: Males have impaired glucose tolerance \\
\hline $\mathrm{Hip}^{-1-}(22,23)$ & Postnatal death & $\begin{array}{l}\text { Pancreas: Impaired morphogenesis, islet formation, and endocrine cell } \\
\text { proliferation (enhanced effect in } \mathrm{HIP}^{-/-} ; \mathrm{Ptc}^{+/-} \text {that die before E13); small } \\
\text { deformed spleen } \\
\text { Stomach: Altered ratio of epithelial-mesenchymal thickness in posterior stomach }\end{array}$ \\
\hline Villin-Hhip (35) & Viable & $\begin{array}{l}\text { Small intestine: Flattened hyperproliferative epithelium; mislocalized ISEMFs; } \\
\text { ectopic precrypt structures }\end{array}$ \\
\hline Gli-1 $1^{-/-}(124)$ & Viable & No obvious defects \\
\hline Gli-2-/- (51) & Perinatal death & $\begin{array}{l}\text { Foregut: Hypoplastic esophagus, with no development of smooth muscle and } \\
\text { small lumen } \\
\text { Hindgut: Imperforate anus with rectourethral fistula }\end{array}$ \\
\hline Gli-3-1- (43) & & Hindgut: Anal stenosis. \\
\hline Gli-2-/-; Gli-3+/- $(43,51)$ & Viable & Foregut and Hindgut: No obvious defects \\
\hline Gli-2-/-; Gli-3+/- & Perinatal & Foregut: EA/TEF \\
\hline Gli-3-1-, Gli-2+/- $(43,51)$ & & Hindgut: Persistent cloaca, less severe than double knockout \\
\hline Gli-2-/-; Gli-3-/- $(43,51)$ & Die: E10.5-E13.5 & $\begin{array}{l}\text { Foregut: Endoderm does not develop into esophagus, trachea, and lungs. Small } \\
\text { hepatic and pancreatic buds } \\
\text { Hindgut: Persistent cloaca, same severity as } \mathrm{Shh}^{-/-}\end{array}$ \\
\hline
\end{tabular}

dose-dependent effect. ${ }^{43}$ Hh signalling is involved in the development of a normal hindgut, and, although probably important to the pathogenesis of human anorectal malformations, this has yet to be studied in detail.

In both $\mathrm{Hb}$ knockouts, there is decreased thickness of the circular smooth muscle layer along the small intestine $34 \%$ reduction for $I h b^{-1-}$ and $21 \%$ for $\mathrm{Shb}^{-1-}$ when compared with wild type). ${ }^{31}$ Both also show abnormalities of the enteric nervous system (ENS). $S h b^{-1-}$ mice have neurons that differentiate abnormally under the epithelium and migrate into the villi. The healthy epithelium is known to inhibit proliferation of enteric neurons, an effect that is lost when Shh signalling is blocked with the general $\mathrm{Hh}$ pathway-inhibitor cyclopamine (Figure 2). ${ }^{45}$ Grafting Shh-expressing cells into the mesenchyme limits neural proliferation in the vicinity. Furthermore, Shh promotes proliferation of neural crest cells while in- hibiting differentiation and modulating their responsiveness to glial cell line-derived neurotrophic factor (GDNF). ${ }^{46}$ Taken together, these data strongly implicate Shh signalling in proper radial patterning of the ENS.

$I h^{-1-}$ mice (and to a lesser extent Gli-3 ${ }^{\Delta 699 / \Delta 699}$ mice $\left.{ }^{44}\right)$ macroscopically exhibit marked dilatation of the small intestine and parts of the colon, corresponding to a microscopic absence of neurones. ${ }^{31}$ Some neurones are present in a normal pattern in patches of nondilated colon. This colonic phenotype is observed with a penetrance of approximately $50 \%$. The inference is that neural crest cells can migrate into the gut and differentiate, but, in the absence of Ihh locally, they fail to survive or proliferate. Interestingly, this phenotype resembles Hirschsprung disease (HSCR) in humans. The 1 study to assess a genetic link failed to associate $I b h$ polymorphisms with HSCR but was probably underpow- 


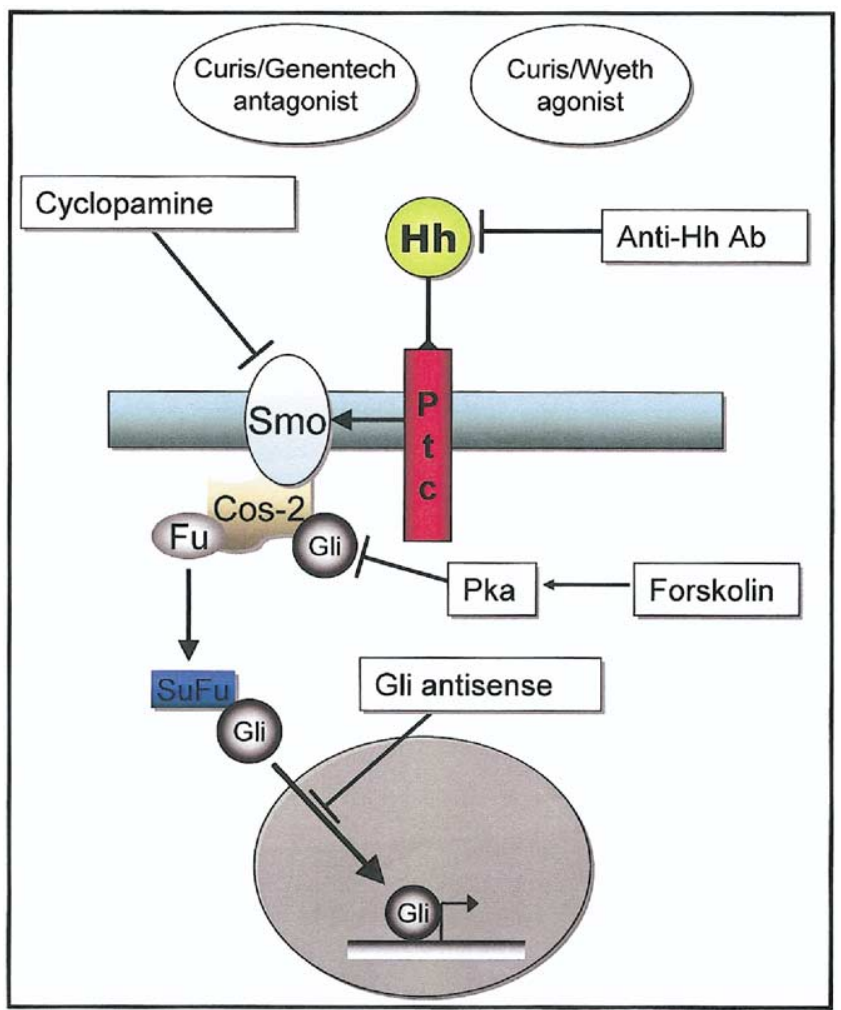

Figure 2. Methods of agonizing/antagonizing the Hh signalling pathway. Shh ligand can be prevented from binding to its receptor, Ptc, by an anti-Shh monoclonal antibody 5E1. ${ }^{117}$ Several specific Smo inhibitors have been identified. Cyclopamine is a natural alkaloid derivate isolated from Veratum californicum, a plant of the lily family long known to be teratogenic to grazing pregnant ewes. ${ }^{118-121}$ Although impractical for human therapeutics because of difficulties of largescale production, blocking $\mathrm{Hh}$ signalling with cyclopamine does appear safe in treated mice. ${ }^{85,88}$ Pka agonists such as Forskolin can decrease pathway activity as they maintain the Gli family of transcription factors in an inactive state. Alternatively blocking Gli RNA with antisense oligonucleotides has been shown to abrogate successfully the Hh pathway activity in Xenopus. ${ }^{122}$ Curis Inc. has developed a small molecule Hh agonist (in partnership with Wyeth) and an antagonist (with Genentech) that have been tested in preclinical models and are now being evaluated in phase I clinical trials (http:// www.curis.com).

ered. ${ }^{47}$ Gene-gene interactions between I $h b$ and the major HSCR genes may play a role.

Ihh is normally expressed in the intervilli region of the small intestine, the presumed stem cell compartment. ${ }^{31,48}$ In the knockout animals, there is decreased size of the villi and a $54 \%$ reduction in cell proliferation in the stem cell compartment. In the colon, these animals also lose the normal monolayer of epithelial cells with crypt organization. ${ }^{49}$ This is replaced by multilayered epithelial cells lacking crypts. These data implicate Ihh in the regulation of stem cell proliferation and possibly epithelial cell migration in the intestine.

The Shb and $I h b$ double knockout embryo arrests development at early somite stages (E8.0). Utilizing the
pan-Hh inhibitor HIP under control of the mouse villin promoter, Madison et al have generated a viable murine model to study the effects of abrogating all $\mathrm{Hh}$ signals in the postnatal small intestine. ${ }^{35}$ The epithelium was noted to be flattened, with significant interference of villus formation and epithelial remodelling. Changes in the mesenchyme (expansion of smooth muscle progenitors and mislocalization of intestinal subepithelial myofibroblasts [ISEMFs]) were found, in turn, to impact further on the epithelium with increased proliferation and enhanced $\beta$-catenin/Tcf 4 activity. In this manner, the Hh pathway patterns the intestinal crypt-villus axis via a paracrine signal.

A further role for Hh signalling in the development and/or function of the murine postnatal intestine has been suggested by Wang et al. ${ }^{34}$ In view of the lethality of $S h b^{-1-}$ and $I b b^{-1-}$ knockout mice above, these authors studied wild-type animals and blocked Hh signalling at late stages of pregnancy and immediately postnatally with the anti-Hh monoclonal antibody 5E1, which blocks Shh, Ihh, and Dhh. All pups died by 3 weeks, having displayed a runting and wasting phenotype postnatally. It is of some interest that this corresponded with the development of significant diarrhea. The small intestines of these animals showed significant histopathological abnormalities, notably disorganized villi projecting into the lumen, and hyperplastic crypts with a 73\% increase in proliferation compared with control animals. Furthermore, a prominent vesicular vacuolation was noted in enterocytes, predominantly affecting ileum and cecum. This defect became apparent only on postnatal day 2 , having been absent 1 day previously even in animals treated with $5 \mathrm{E} 1$ from E12.5. It was also noted to be an intestinal-specific phenomenon with no such vacuolation identified in other cell types, including hepatocytes. Further characterization showed that these vacuoles represent an intracellular accumulation of neutral lipid (Oil Red O positive, PAS negative). The possible involvement of Hh signalling postnatally in lipid absorption and secretion is also suggested by the numerous microscopic fat droplets in the stool of treated mice and by decreases in serum apolipoprotein A-IV, total cholesterol, and high-density lipoprotein cholesterol in these animals.

This is further supported by a recent study in adults, demonstrating that monoclonal antibody-mediated inactivation of $\mathrm{Hh}$ signalling in mice fed a high-fat diet protects against weight gain. ${ }^{50}$ Similarly treated leptindeficient mice $(o b-a b)$ that ordinarily gain weight on a low-fat diet showed decreased weight gain compared with controls. Although total lipid absorption was normal, the rate of triglyceride absorption was significantly 
slowed, and there was increased fecal, free-fatty-acid excretion in the mAb-treated animals. Indeed, the hepatic steatosis noted in the high-fat control group was abolished with abrogation of Hh signalling. However, these data need to be interpreted with caution because detailed studies of cyclopamine-treated animals demonstrate increased $\mathrm{Wnt} / \beta$-catenin activity and colonic cancers $^{49}$ (discussed in detail later). This could account for at least a proportion of the weight loss demonstrated here.

\section{Shh, Foregut Development, and Esophageal Fistula/Tracheoesophageal Fistula}

The development of esophageal fistula/tracheoesophageal fistula (EA/TEF) in $S h b^{-1-}$ mice suggests a role for Hh signalling in the pathogenesis of this condition and in normal foregut development. ${ }^{30,31}$ Furthermore, the human Gli genes are implicated in congenital foregut malformations by the significant abnormalities noted in the Gli-2 and Gli-3 knockout mice (Table 1). ${ }^{51}$ In normal murine development, foregut expression of Shh is particularly high when the trachea and esophagus split. ${ }^{52,53}$ At E10.5, the normal undivided foregut has a ventrally placed prospective trachea that is positive for Shh. ${ }^{54}$ By E11.5, this pattern is reversed with the separated trachea now negative for Shh. ${ }^{30,54}$ However, analysis of the adriamycin-induced rat model of EA/TEF shows that, when the trachea is still undivided (at E11.5 in the rat, a slightly different developmental time point to the mouse), there is a diffuse Shh staining pattern that lacks any dorsal-ventral gradient. ${ }^{54}$ The rat fistula tract shows much lower Gli-2 levels than the adjacent esophagus. ${ }^{55}$ Furthermore, culture of fistula tract with exogenous Shh induces branching, a known Shh effect on the developing lung. ${ }^{55}$ Examination of one resected human fistula tract in a newborn showed Shh in the proximal esophageal pouch but not in the distal fistula tract. ${ }^{56}$

Combined, these data show that the fistula tract is of respiratory, not esophageal, origin. Shh is vital to the normal development of the esophagus and trachea and heavily involved in the pathogenesis of EA/TEF and VACTERL (vertebral, anal, cardiac, tracheoesophageal fistula, radial, renal, and limb abnormalities) association that the adriamycin model mimics. In humans, both foregut and hindgut anomalies are seen in some patients with holoprosencephaly (where mutant $S h b$ causes cyclopia). Because EA/TEF in humans do not appear to be caused by genetic defects, an environmental association in the early embryo that manipulates $\mathrm{Hh}$ signalling is more probable than a $\mathrm{Hb}$ mutation. What the relevant trigger is remains unclear, although it has been shown to be unrelated to maternal cocaine use as had been hypothesized. ${ }^{57}$

\section{Pancreatic Development}

In contrast to the positive role played by Shh in many tissues and organs, Shh inhibits pancreas morphogenesis and cell differentiation. ${ }^{58}$ Loss of Shh in prospective pancreatic endoderm is a critical step in normal pancreatic development. ${ }^{41}$ Indeed, ectopic expression of Shh leads to disrupted expression of pancreatic markers and pancreatic morphogenesis. ${ }^{59}$ Cyclopamine treatment of developing chicks allows ectopic budding of pancreatic structures and expression of pancreatic markers in the stomach and duodenum. ${ }^{60}$ The $\mathrm{Hb}$ knockout mice have increased pancreatic mass and subsequently an annular pancreas that mirrors the rare human congenital malformation. ${ }^{31,36,61}$ Shh appears to inhibit pancreatic development and growth by its local expression in the developing stomach and duodenum. Decreased local $\mathrm{Hh}$ signals allow ectopic branching of ventral pancreatic tissue that causes an annulus around the duodenum. $\mathrm{Hb}$ knockout embryos also demonstrate relatively increased pancreatic $\beta$-cell and $\alpha$-cell numbers, $S h b^{-1-}$ more than $I h h^{-1-}{ }^{36}$ Furthermore, $S h b^{-1-}$ mice have increased gastric glucagon-positive cells, indicating that Hh blocks endocrine cell differentiation in the pancreas and the stomach. ${ }^{36}$ The pathway inhibitors HIP and Ptc-1 are also required for normal pancreatic development as demonstrated in knockout mice $\left(\mathrm{HIP}^{-1-}\right.$ and $\left.\mathrm{HIP}^{-1-} ; \mathrm{Ptc}^{+/-}\right)$ in which pancreatic growth and endodermal cell differentiation are impaired. ${ }^{23}$

\section{Hh Signalling in Adult Health}

\section{Patterns of Expression in the Adult GI Tract}

The main published survey of the Hh signalling pathway in the GI system in adult humans and rodents was carried out by Van den Brink et al (Table 2). ${ }^{62}$ These authors demonstrated Shh mRNA to be abundantly expressed in the gastric fundus, in small quantities in the crypts of the small intestine, and in a few colonic crypts but not in the esophagus or gastric antrum. ${ }^{1,62}$ When the authors used commercially available goat polyclonal antiShh antibody, they did not find any positive staining for Shh protein anywhere apart from in the gastric fundus. ${ }^{62}$

Subsequently, work from 3 separate teams has now shown that Shh protein is present in the human colon. ${ }^{1,63,64}$ Oniscu et al in Edinburgh found protein in the cytoplasm at the top of normal colonic crypts. ${ }^{64}$ This localization was confirmed by the presence of Shh mRNA in laser microdissected crypts. Similar protein findings are reported by Dimmler et al, who show Shh expression in the distal colon only. ${ }^{63}$ Most recently, Nielson et al have reported the presence of Shh mRNA by in situ hybridization and protein by immunohistochemistry in 
Table 2. Expression of Shh, Ihh, and Ptc-1 in the Human Adult Gl Tract

\begin{tabular}{|c|c|c|c|c|c|c|}
\hline & Esophagus & Stomach & Small intestine & Colon & Liver & Pancreas \\
\hline Shh protein & - & + & + & + & $?$ & - \\
\hline Shh mRNA & - & + & + & + & ? & - \\
\hline Ihh protein & ? & ? & ? & + & + & + \\
\hline Dhh protein & $?$ & ? & ? & ? & ? & + \\
\hline Ptc-1 protein & Background & + & + & + & ? & + \\
\hline
\end{tabular}

NOTE. There are no published data for expression of Ptc-2 or Gli-1, -2, and -3 in any of these locations or Dhh anywhere other than the pancreas. +, Present; -, absent; ?, data not published.

small intestinal and colonic crypts, predominantly in the bases but with some focal surface epithelial expression. ${ }^{1}$

The discrepancy in protein data likely reflects varying protein detection sensitivities in differing immunohistochemistry protocols because different laboratories used the same antibody. It may also reflect differences in colonic sampling if the differential expression of Shh across the colon suggested by Dimmler et al is borne out in larger data sets. This finding warrants further investigation in light of newly published data demonstrating differential expression of many different genes in the right and left colon. ${ }^{65}$ Alternatively, it is possible that Shh mRNA synthesis occurs at the crypt base, with translation into protein happening as cells differentiate as they migrate toward the lumen.

Van den Brink et al have subsequently shown expression of Ihh mRNA and protein in the human colon localizing to surface absorptive enterocytes. ${ }^{49}$ These same cells were negative for Shh mRNA by in situ hybridization. ${ }^{62}$ Little is known of Ihh expression in the rest of the luminal digestive tract, but it is present in the pancreas (see below), in which Shh is absent, and in the liver. ${ }^{66}$

Further data are required to assess whether the $2 \mathrm{Hh}$ homologues occupy distinct niches within the colon or whether they overlap and perform different biologic functions. Given the important function of Shh expression gradients during development, it seems likely that gradients of differential Shh/Ihh expression persist within the adult digestive tract. These may function to maintain structural and functional boundaries and/or maintain stem cell populations. Blocking Hh signalling with cyclopamine is smoothened (Smo) specific, and the anti-Shh monoclonal antibody 5E1 (Figure 2) also blocks Ihh. Neither agent will therefore help distinguish between Shh and Ihh function. There are no published data examining Dhh expression in the adult mammalian digestive tract (Table 2).

Ptc-1 mRNA and protein are expressed in similar locations to Shh in the adult human gut. Although minimal Ptc- 1 has been detected in the esophagus, there is abundant expression in the glands of the stomach. ${ }^{1}$ mRNA was present in the base of the villi and the lamina propria of the small intestine, with protein also detected in the tips of villi. ${ }^{1}$ In the colon, mRNA and protein have been detected in the luminal epithelium and subadjacent lamina propria by Nielson et $\mathrm{al}^{1}$ and also basally in isolated crypt cells by Oniscu et al. ${ }^{64}$ Further characterization of the population of Ptc-1-positive cells in the lamina propria, as well as the basally located cells (suggested to be neuroendocrine in origin ${ }^{64}$ ) is required. Smo protein is only found at the brush border of the superficial colonic epithelium. ${ }^{64}$ There are no data for Gli1-3 protein expression in the adult GI tract; however, a functional role remains probable, given the developmental data. Analysis of fetal and adult colonic mRNA by reverse-transcription polymerase chain reaction (RTPCR) confirms expression, if not location, of all essential Hh signalling components (Shh, Ptc-1, Smo, Gli1, Gli2, and Gli3). ${ }^{67}$

\section{Functional Aspects of Hh Signalling in the Adult GI Tract}

Shh as a Polarizing Signal for Fundic Gland Differentiation in the Stomach. Within the stomach, there are 2 compartments relative to the position of the epithelial stem cell. In the pit region, cells are migrating toward the gastric lumen, and, in the gland region, they migrate in the opposite direction. Shh expression is restricted to the glandular portion of both human and murine stomach (utilizing gastric mucins as genetic markers for each compartment). In humans, Shh expression has been shown by Van den Brink et al to be greatest at the pit-gland transition and restricted to parietal cells (as confirmed by double staining with $\mathrm{H}^{+} \mathrm{K}^{+}$ATPase). ${ }^{63,68}$ Ptc- 1 is expressed on the epithelial cells of the gastric gland region and some of the interstitial cells. Pit cells are Ptc-1 negative, but parietal cells and epithelial cells at the base of the glands express Ptc-1.68

Shh expression correlates with fundic gland type, as seen where there is loss or gain of fundic gland differentiation. In chronic gastritis, in which there is intestinal metaplasia (as identified by the presence of MUC2), there is a loss of Shh expression. ${ }^{68}$ However, Dimmler et al suggest that this may be related to the process of atrophy because Shh is highly expressed in nonatrophic gastri- 
tis. ${ }^{63}$ In the esophagus, Shh is present in parietal cells $\left(\mathrm{H}^{+} \mathrm{K}^{+}\right.$ATPase positive) when they are present in Barrett's resection specimens. Areas of Meckel's diverticulum containing parietal cells are also positive for Shh expression. ${ }^{68}$

These data show that Shh may play a role as an essential polarizing signal for fundic gland differentiation. It has been postulated that an intestinal epithelium may be the default state during development. Shh expression is part of a regulatory network that induces the character of gastric epithelium compared with intestinal type. This is then maintained by Shh signalling throughout adult life.

Ihh and Regulation of Colonic Enterocyte Differentiation. Cyclopamine treatment markedly alters the slender nucleus and cytoplasm of normal terminally differentiated enterocytes. Without $\mathrm{Hh}$ pathway activity the enterocytes at the luminal end of the crypt have an enlarged nucleus and large cytoplasm. In addition, they show significantly altered expression of 3 molecular markers of enterocyte differentiation, with redistribution of villin to the cytoplasm, decreased carbonic anhydrase, and increased intestinal trefoil factor. ${ }^{49}$ In the HT-29 colon carcinoma differentiation model, treatment of cells with butyrate induces expression of villin and Cip-1 and induces Ihh expression. Blocking Hh signalling with cyclopamine substantially decreases the Cip- 1 and villin induction with butyrate. In addition, giving recombinant N-terminal Shh (91\% homologous to Ihh) leads to induction of Cip-1 and villin. These data suggest a role for Ihh in regulating colonic epithelial differentiation in vivo and in vitro.

Furthermore, Hh signalling restricts expression of BMP-4 (a Dpp homolog coexpressed with $\mathrm{Hh}$ genes during development) and engrailed-1 (a Wnt target gene) to the precursor cell compartment at the base of the colonic crypt. $\beta$-Catenin-TCF (a marker of Wnt pathway activity) signalling can be completely abrogated by Ihh in colon cancer cells. ${ }^{49}$

Where Wnt pathway activity is constitutively overexpressed (adenomatous polyposis coli [APC] gene mutations in familial adenomatous polyposis), Ihh expression is lost. This phenomenon is observed in familial adenomatous polyposis (FAP) resection specimens that contain both normal and dysplastic epithelial cells (corresponding to APC mutations and Wnt overactivity). Normal Ihh expression is noted in the normal epithelial cells, but this is lost in dysplastic cells.

Inhibiting $\beta$-catenin-TCF signalling in colon cancer cells causes rapid induction of Ihh expression. These data together indicate that Ihh expression is negatively regulated by $\beta$-catenin-TCF signalling. Furthermore, de- creased Ihh expression in colonic polyps is seen in response to the Wnt-activating APC mutation. Because the loss of differentiation observed in the cyclopaminetreated colonic epithelial cells mirrors that seen in colorectal carcinogenesis, loss of thh may have a role to play in the development of dysplasia. ${ }^{49}$

As discussed, all methods currently available to manipulate Hh pathway activity are nonspecific for Shh or Ihh. The reported data are heavily reliant on expression studies, and, as previously shown, there remains some conflict with other published literature (as is further discussed below in the specific context of colon cancer). It is therefore once again difficult to ascribe the effects seen here to one Hh homologue or another. Greater specificity could now be achieved through the appropriate application of RNA interference technology, utilizing specific sequences of double-stranded RNA to knock down the expression of complementary genes and determine the relative contributions of Shh and Ihh in homeostasis of the adult digestive tract.

Ihh and the Adult Pancreas. In contrast to the negative influence of Shh on developing pancreatic growth, there does appear to be a role for Ihh in the adult pancreas. Ihh (and to a lesser extent Dhh) is expressed in islet and $\beta$-cells in characteristic small, highly localized aggregates or punctates. ${ }^{37,69,70}$ Ptc- 1 and Smo have been shown to be expressed in islets, localized to $\beta$-cells by coexpression with insulin. The insulin-secreting clonal cell line INS-1 expresses Ihh, Ptc-1, and Smo. Activation of the Hh signalling pathway by ectopic misexpression of Shh increased activity of the rat insulin I promoter. ${ }^{37}$ The administration of cyclopamine decreased insulin I promoter activity, decreased insulin secretion, and insulin content of these cells in a concentration-dependent manner. ${ }^{37}$ These data imply that the Hh signalling pathway plays an important role in the regulation of insulin production in the murine pancreas. The expression data suggest that Ihh and Dhh are the active Hh homologues in this process. However, the functional data described used Shh to activate Hh signalling, and cyclopamine to block pathway activity in a manner not specific for any Hh homologue, so there remains a degree of uncertainty.

\section{Hh Signalling and GI Disease}

We have seen that Hh signalling is critical to normal GI development and that it may have an important role to play in homeostatic processes of the adult stomach, colon, and pancreas. These processes rely on time-dependent and tissue-specific signalling at distinct concentrations. This is made possible by differential expression of $\mathrm{Hh}$ signalling components, the tight positive 
transcriptional and negative feedback loops (created by ligand-induced activation of negative regulators, Ptc and Hip1), regulatory interactions with $\mathrm{WnT} / \beta$-catenin signalling, and the pathway's ability to function as a bistable genetic switch, flipping cell fates at precise, threshold Shh concentrations. ${ }^{71}$

However, as a result of this reliance on such tight control, increases or decreases in pathway activity can result in severe defects. It is important to consider how a developmental pathway that normally directs differentiation and proliferation may, with the loss of its normal strict controls, contribute to cancer formation and maintenance and chronic intestinal inflammation.

\section{Hedgehog Signalling and Tumorigenesis}

The Hh signalling pathway interacts directly with cell-cycle components to increase cell proliferation. The G1-S transition is promoted by cyclins D and E, both transcriptional targets of $\mathrm{Ci}$ in Drosophila, ${ }^{72}$ a finding confirmed in mammalian cells. ${ }^{73}$ The G2-M transition is in part controlled by Ptc, which regulates the activation of cyclin B (part of the mitosis-promotingfactor complex). ${ }^{74}$ Shh also blocks p $21^{\text {(CIP1/WAF1) }}$-induced growth arrest. ${ }^{75}$ Furthermore, there is some evidence that Ptc, like deleted in colorectal cancer (DCC), UNC5, and RET, functions as a dependence receptor. ${ }^{76,77}$ Dependence receptors are characterized by a cellular state of dependence on their ligand, such that absence of ligand induces apoptosis. ${ }^{78}$ The presence of ligand $(\mathrm{Hh})$ prevents the induction of apoptosis (Figure $1 B$ ). In the absence of $\mathrm{Hh}$, caspase-3-mediated cleavage of the intracellular Ptc domain exposes a receptor region that transduces the apoptotic signal via Gli-3 (Figure 1A). It is noteworthy that many of the $\mathrm{Hh}$ pathway activating Ptc-1 mutations implicated in central nervous system (CNS), skin, and muscle tumors map to the carboxyterminus in the vicinity of the caspase- 3 site. ${ }^{79}$ Such critical functions as cell cycle control help to explain the importance of tight, multilayered control on the pathway. It is perhaps, however, not surprising to learn that Hh signalling is implicated in the induction and maintenance of cancer. ${ }^{80-84}$ This is, in part, by promoting cell cycle proliferation and opposing the normal stimuli for cell cycle arrest.

To date, aberrant Hh signalling has been described in tumors of the skin, brain, lung, and digestive tracts. ${ }^{81,85-89}$ A subset of Hh-responsive cancers is, in part, caused by mutations in Hh pathway components. This phenomenon was first identified in patients with Gorlin syndrome, who, along with generalized body overgrowth, cysts, and skeletal developmental abnormalities, have a predisposition to benign and malignant neoplasia, notably multiple basal cell carcinomas. ${ }^{90,91}$ Patients inherit a mutant $P t c$ that permits constitutive pathway activation. A mutation in Ptc is also present in a proportion of medulloblastomas and rhabdomyosarcomas, in which there is evidence that this confers on tumor cells the ability to resist apoptosis. ${ }^{92}$ This loss of function phenotype defines Ptc as a tumor suppressor gene and is consistent with its role as a dependence receptor. Somatic mutations in the Ptc gene are reported in esophageal squamous cell carcinomas and transitional cell carcinomas of the bladder. ${ }^{93,94}$ Other oncogenic mutations include Smo in basal cell carcinoma (in which the pathway becomes independent of Hh-Ptc binding) ${ }^{95}$ and $\mathrm{SuFu}$ in medulloblastoma, ${ }^{96}$ whereas ectopic expression of Gli causes glioma. ${ }^{97}$

It is now known that the Hh pathway is also involved in the formation and maintenance of some sporadic tumors without implicating pathway activating mutations. This is seen to be the case for small cell lung cancer, ${ }^{89}$ prostate cancer, ${ }^{98}$ pancreatic cancer ${ }^{88}$ cholangiocarcinoma, and other tumors of the digestive tract. ${ }^{86}$

\section{Pancreatic Cancer}

Although Shh and Ptc-1 are not detected in normal adult human pancreata, Shh is aberrantly expressed in pancreatic adenocarcinoma and its precursor lesions. ${ }^{88}$ With the increasing degree of atypia observed in the ductal epithelium through the precursor lesions (panIN-1 to -3), there is increasing Shh expression. Ihh is present in normal pancreatic islet cells, and up-regulated in adenocarcinomas, both in islets and in cancer cells. ${ }^{70}$ Ptc- 1 protein is present in the abnormal epithelium and the surrounding reactive mesenchymal cells of human neoplastic pancreata. Ptc- 1 mRNA levels are up to 5000-fold higher in pancreatic tumors than in adjacent normal tissue, ${ }^{86}$ although there is wide variation in this figure, and a much more conservative up-regulation of Ptc- 1 is suggested by Kayed et al. ${ }^{70}$ Smo is also over-expressed in neoplastic tissue. Thayer et al have further explored this association using a $P d x-1-S h b$ mouse model that generates misexpression of Shh in the pancreas (by using the pancreatic-specific $P d x-1$ promoter to drive Shh expression). ${ }^{88}$ These transgenic animals show abnormal pancreatic development, with morphologic changes resembling human ductal PanIN. They also develop similar genetic changes to pancreatic adenocarcinomas-overexpression of epithelial Her2/neu, and occasional K-Ras mutations. ${ }^{99-101}$ Unfortunately, $P d x 1-S h b$ mice die at 3 weeks of age, so another model will be required to assess the impact of Hh signalling on metastatic progression of pancreatic lesions. 
Pancreatic adenocarcinoma cell lines from both primary and metastatic tumors show sustained Hh signalling activity. ${ }^{88}$ This has been confirmed by demonstrating significantly elevated luciferase activity on transfection of a Gli-luciferase reporter construct into these cell lines. Most cell lines express Smo, and of those half respond to cyclopamine treatment with increased apoptosis (2.5- to 3.5-fold), decreased cell proliferation (up to $75 \%-80 \%$ ), and abolished luciferase activity. ${ }^{88}$ Kayed et al has shown this decreased cell proliferation to be due to $G_{0} / G_{1}$ cell cycle accumulation. ${ }^{70}$ The lack of response in the remaining half suggests that mutations in other Hh components, downstream of Smo, contribute to the abnormal proliferation. It must also be considered that mutations in Hh-independent pathways play a role in these cyclopamine-resistant cell lines.

The ability of cyclopamine to inhibit tumor cell growth has been confirmed by Thayer et al in vivo. ${ }^{88}$ Cyclopamine-sensitive cells injected into a nude mouse were treated with cyclopamine either concurrently from initiation or delayed until subcutaneous tumors were palpable. The latter group showed a 50\%-60\% decrease in tumor mass compared with controls, a figure that increased to an $84 \%$ reduction in the concurrent group. The treated tumors were seen as loose epithelial cell aggregates with a 6-fold increase in apoptotic cells by TUNEL assay. The effective cessation of ligand-dependent Hh signalling does not apparently cause these mice any unwanted effects, a finding confirmed in other studies. $85,86,88,89$

Interestingly, the Hh inhibitor Hip1 may play a role in pancreatic tumorigenesis. Hip1 expression is lost in most pancreatic adenocarcinoma cell lines, ${ }^{88}$ and Hip$1^{-1-}$ mice, although dying shortly after birth, ${ }^{22}$ show increased pancreatic Hh signalling during development (Table 1). ${ }^{23}$ Genetic analysis of a family with a very high frequency of pancreatic adenocarcinoma has mapped the genetic location responsible to the chromosomal region $4 \mathrm{q} 32-34 .{ }^{102} \mathrm{Hip}-1$ is located immediately adjacent to this region, suggesting that a mutation in this gene may activate pancreatic $\mathrm{Hh}$ signalling and thereby initiate and maintain tumor formation.

\section{Other Cancers of the Upper GI Tract}

The Hh signalling pathway is active in many digestive tract cell lines. Shh and Ihh mRNA is present in virtually all cell lines from esophageal, stomach, biliary tract, pancreatic, and colonic carcinomas. However, Ptc-1 and Gli, used as markers of Hh pathway activity, are coexpressed only in esophageal (4/6), stomach (6/6), biliary tract $(5 / 9)$, and pancreatic $(5 / 6)$ tumors (numbers in parentheses refer to cell lines). In these cell lines, the
Gli-luciferase reporter assay shows a high level of activity and therefore confirms autonomous pathway activity. Of the Ptc-1 mRNA-positive cell lines, treatment with cyclopamine resulted in a 75\%-95\% decrease in growth Ptc-1-negative cell lines show no difference in growth with cyclopamine treatment.

The dramatic in vivo responses of pancreatic tumors to Hh blockade have been paralleled by experiments described by Berman et al, who have studied murine xenografts created from a human metastatic cholangiocarcinoma cell line. ${ }^{86} 180 \mathrm{~mm}^{3}$ tumors treated with cyclopamine regressed completely in 12 days and remained histologically undetectable in mice that by 3 months post treatment had shown no ill effects of the cyclopamine treatment. The control animals killed at 22 days had tumors averaging $800 \mathrm{~mm}^{3}$. In contrast to the constitutional activation of $\mathrm{Hh}$ signalling caused by mutant Ptc-1 in Gorlin syndrome, these tumors are dependent on Hh-ligand for growth. This has been demonstrated by the concentration-dependent decrease in tumor growth and luciferase activity with the ligand blockade (Shh and Ihh) achieved using the 5E1 monoclonal antibody (Figure 2). ${ }^{86}$ Tumor growth was partly rescued with the addition of endogenous Shh.

\section{Colon Cancer}

Although the survey of digestive tract tumors by Berman et al failed to establish active Hh signalling within a panel of 11 cell lines, Shh and Ihh mRNA were detected in all cell lines, and Gli was present in 4 out of 11. Furthermore, Qualtrough et al have shown expression of mRNA and protein of Shh, Ihh, Ptc-1, Smo, and Gli1 in all 5 cell lines they tested. ${ }^{103}$ Of these, the adenoma-derived cell lines (AA/C1 and $\mathrm{RG} / \mathrm{C} 2$ ) have higher levels of Ihh expression than the adenocarcinomaderived lines (CaCo2, HT29, and SW480) but slightly lower levels of Ptc-1, Smo, and Gli. These observations may reflect the evolving role of $\mathrm{Hh}$ signalling with tumor phenotypic progression. All these cell lines, however, show a dose-dependent response to cyclopamine treatment, with decreased cell yield, increased apoptosis, and decrease in autocrine Hh signalling (decreased Gliluciferase reporter activity). This effect is partially rescued with endogenous Shh-N protein. Similarly, Oniscu et al demonstrate Shh to have a mitogenic effect on colonic cell lines that is reversible with cyclopamine. ${ }^{64}$ Furthermore, these authors were able to show increased Shh, Ptc-1, and Smo expression in resected human adenocarcinomas, with intermediate levels in dysplastic tissue and benign adenomas.

Together, these results suggest a functional role for the $\mathrm{Hh}$ pathway in maintenance of colonic cancer 
growth. However, there is a significant discrepancy with the observation of Van den Brink et al that loss of Ihh expression may be an important step to the establishment of the malignant colonic phenotype, as discussed above. ${ }^{49}$ Although the different $\mathrm{Hh}$ homologues share very similar signalling properties such as providing a proliferative stimulus to epithelia, 2 factors help explain the conflicting data in the healthy and malignant colon. First, in certain situations, Shh and Ihh have distinct biologic functions, as demonstrated in the digit duplication studies by Pathi et al. ${ }^{4}$ Second, location of Shh and Ihh within distinct compartments of the colon is probably functionally important. With this in mind, it has been suggested that Shh provides the proliferative stimulus in the colon, whereas Ihh promotes epithelial differentiation by inhibiting proliferation. ${ }^{104}$ We suggest that a greater understanding of the colonic distribution of Shh and Ihh and their relative local biologic properties is needed to help further unify these data.

There is evidence that redundancy and cross talk within the Hh signalling pathway may prevent effective blockade in some cancers. ${ }^{105,106}$ Therefore, further clarification of the mechanistic links between Hh signalling and carcinogenesis will be critical to the translation of this research into successful chemotherapeutic strategies. It is equally important to determine why only certain subsets of GI malignancy demonstrate dysregulated Hh signalling and to clarify the differences demonstrated between the upper and lower digestive tract. Once these further data are available, it may then be possible to identify patient subpopulations that will derive the greatest clinical benefit from complete abrogation of the Hh signal.

\section{Hedgehog Signalling and Chronic Inflammation in the GI Tract}

There is increasing evidence to implicate a recapitulation of embryonic $\mathrm{Hh}$ signalling in normal and pathogenic inflammation. This has been shown in response to several insults, including acute epithelial injury, skeletal muscle ischemia, ${ }^{107}$ bone fracture, ${ }^{108}$ and chronic pancreatitis. ${ }^{69}$ In the latter, there is increased Ihh, Ptc-1, and Smo with expression identified in the cells forming tubular complexes and in the islets (with loss of the punctuate staining pattern seen previously). ${ }^{69}$ In the lung epithelium, there is extensive activation of the $\mathrm{Hh}$ pathway in response to acute airway injury ${ }^{89}$ and in chronic lung fibrosis. ${ }^{109}$ Much of the work done in the lung suggests that Shh (like KGF and FGF-10110,111) is involved in repair to epithelial injury, with the primary aim of restoring continuity to areas of denuded epithe- lium, thus minimizing input of pathogenic agents across this barrier.

Our group has shown Shh-mediated signalling to be a physiologic component of peripheral T-lymphocyte responses $^{109,112,113}$ (reviewed in Benson et al ${ }^{114}$ ). Shh acts to modulate $\mathrm{CD} 4+$ T-cell effector function, ${ }^{113}$ with endogenously produced Shh playing a role in sustaining normal CD4+ T-cell proliferation. ${ }^{112}$ This response was enhanced by adding exogenous Shh. We suggest that the pathway's role in the remodelling of injured pulmonary epithelium is in part mediated by Hh-ligand communication of tissue injury to Ptc-1-positive immune cells, including CD4+ T lymphocytes and macrophages. ${ }^{109}$

The critical question as to whether $\mathrm{Hh}$ signalling is protective or whether it is pathogenic remains unanswered. In some immunopathologic disorders, the Shh pathway functions as a possible repair mechanism, but it could also have a damaging effect. ${ }^{114}$ Intriguingly, the proinflammatory mediator NF- $\kappa \mathrm{B}$ appears to up-regulate Shh expression (http://www.mgh.harvard.edu/gensurg/ gensurg_research.htm).

Recent preliminary findings from Nielson et al suggest that Shh may be up-regulated in areas of chronic GI inflammation. ${ }^{1}$ This was shown by immunohistochemistry and in situ hybridization in Barrett's esophagus, gastritis, Crohn's disease, and ulcerative colitis. Although not quantitative, the authors' findings show that, during chronic inflammation, mRNA expression was strong throughout the epithelium from base to lumen, with loss of the crypt-villous pattern normally identified in normal intestinal tissues. The authors also report increased Shh protein expression, although this is not readily evident in the published photographs. Ptc-1 mRNA and protein were expressed in metaplastic and regenerating epithelial cells and in the crypts but not in the inflamed colonic surface epithelium. Inflammatory cells in inflamed mucosa stained for Shh and Ptc-1 protein and mRNA. The extension of Shh mRNA from crypt base to include luminal epithelium may represent either expansion of the stem cell compartment or delayed differentiation.

As in acute epithelial injury in the lung, Hh may serve a protective function in acute GI epithelial injury. In a purely hypothetic model, it is suggested that injured epithelium, via the release of Shh, may communicate damage to both neighboring epithelial cells via an autocrine signal and to CD4 $+\mathrm{T}$ lymphocytes, macrophages, and intestinal subepithelial myofibroblasts in the lamina propria that express Ptc- 1 and are thus capable of processing a Shh signal. This process could help repair damaged epithelium by local signals and communication with the immune system. 
Could Hh signalling play a role in cancers arising in areas of chronic inflammation? Beachy et al hypothesize that these cancers represent the continuous operation of an up-regulated state of tissue repair associated with chronic activation of pathways such as $\mathrm{Hh}$ and Wnt. ${ }^{115}$ This is compatible with the probability that increasing cellular resistance to injury and death creates an epithelium populated by genetically damaged cells. Additionally, the persistence of stem cells or the abnormal distribution of Shh may contribute to the malignant transformation. This may have implications for the prevention, diagnosis, and treatment of colitis-associated cancer, adenocarcinomas arising out of Barrett's esophagus, cholangiocarcinomas in primary sclerosing cholangitis, and even hepatomas arising on a background of cirrhosis.

\section{Conclusion}

The GI system provides a clear illustration of how the study of one embryonic signalling pathway can inform such diverse disciplines as molecular biology, tumor biology, stem cell research, and immunology. Further understanding will arise as the complex interactions between $\mathrm{Hh}$ signalling and the other pathways involved in GI development (BMP, Notch, and Wnt/ $\beta$-catenin) are unravelled. In the meantime, the clinical applications of this laboratory research effort are coming closer to realization. This is perhaps best illustrated with pancreatic cancer, in which there exists the possibility of not only improving diagnosis (by examining pancreatic juices for increased concentrations of Hh components) but also developing new treatments by abrogating the Hh signal that drives tumor growth. ${ }^{86,88,106}$

\section{References}

1. Nielsen CM, Williams J, Van Den Brink GR, Lauwers GY, Roberts DJ. Hh pathway expression in human gut tissues and in inflammatory gut diseases. Lab Invest 2004;84:1631-1642.

2. Nusslein-Volhard C, Wieschaus E. Mutations affecting segment number and polarity in Drosophila. Nature 1980;287:795-801.

3. Ingham PW, McMahon AP. Hedgehog signaling in animal development: paradigms and principles. Genes Dev 2001;15:30593087.

4. Pathi S, Pagan-Westphal S, Baker DP, Garber EA, Rayhorn P, Bumcrot D, Tabin CJ, Blake PR, Williams KP. Comparative biological responses to human Sonic, Indian, and Desert hedgehog. Mech Dev 2001;106:107-117.

5. Bellaiche Y, The I, Perrimon N. Tout-velu is a Drosophila homologue of the putative tumour suppressor EXT-1 and is needed for Hh diffusion. Nature 1998;394:85-88.

6. Han C, Belenkaya TY, Wang B, Lin X. Drosophila glypicans control the cell-to-cell movement of Hedgehog by a dynaminindependent process. Development 2004;131:601-611.

7. Mann RK, Beachy PA. Novel lipid modifications of secreted protein signals. Annu Rev Biochem 2004;73:891-923.
8. Carpenter D, Stone DM, Brush J, Ryan A, Armanini M, Frantz G, Rosenthal A, De Sauvage FJ. Characterization of two patched receptors for the vertebrate hedgehog protein family. Proc Natl Acad Sci U S A 1998;95:13630-13634.

9. Motoyama J, Takabatake T, Takeshima K, Hui C. Ptch2, a second mouse patched gene is co-expressed with Sonic hedgehog. Nat Genet 1998;18:104-106.

10. St. Jacques B, Dassule HR, Karavanova I, Botchkarev VA, Li J, Danielian PS, McMahon JA, Lewis PM, Paus R, McMahon AP. Sonic hedgehog signaling is essential for hair development. Curr Biol 1998;8:1058-1068.

11. Lum L, Beachy PA. The Hedgehog Response Network: sensors, switches, and routers. Science 2004;304:1755-1759.

12. Bumcrot DA, Takada R, McMahon AP. Proteolytic processing yields two secreted forms of sonic hedgehog. Mol Cell Biol 1995;15:2294-2303.

13. Lee JJ, Ekker SC, von Kessler DP, Porter JA, Sun BI, Beachy PA. Autoproteolysis in hedgehog protein biogenesis. Science 1994; 266:1528-1537.

14. Porter JA, Young KE, Beachy PA. Cholesterol modification of hedgehog signaling proteins in animal development. Science 1996;274:255-259.

15. Pepinsky RB, Zeng C, Wen D, Rayhorn P, Baker DP, Williams KP, Bixler SA, Ambrose CM, Garber EA, Miatkowski K, Taylor FR, Wang EA, Galdes A. Identification of a palmitic acid-modified form of human Sonic hedgehog. J Biol Chem 1998;273:1403714045

16. Burke R, Nellen D, Bellotto M, Hafen E, Senti KA, Dickson BJ, Basler K. Dispatched, a novel sterol-sensing domain protein dedicated to the release of cholesterol-modified hedgehog from signaling cells. Cell 1999;99:803-815.

17. Tian H, Jeong J, Harfe BD, Tabin CJ, McMahon AP. Mouse Disp1 is required in sonic hedgehog-expressing cells for paracrine activity of the cholesterol-modified ligand. Development 2005; 132:133-142.

18. Bijlsma MF, Spek CA, Peppelenbosch MP. Hedgehog: an unusual signal transducer. Bioessays 2004;26:387-394.

19. Kalderon D. Similarities between the hedgehog and Wnt signaling pathways. Trends Cell Biol 2002;12:523-531.

20. Nusse R. Wnts and hedgehogs: lipid-modified proteins and similarities in signaling mechanisms at the cell surface. Development 2003;130:5297-5305.

21. Chuang PT, McMahon AP. Vertebrate hedgehog signalling modulated by induction of a Hedgehog-binding protein. Nature 1999; 397:617-621.

22. Chuang PT, Kawcak T, McMahon AP. Feedback control of mammalian hedgehog signaling by the hedgehog-binding protein, Hip1, modulates Fgf signaling during branching morphogenesis of the lung. Genes Dev 2003;17:342-347.

23. Kawahira H, Ma NH, Tzanakakis ES, McMahon AP, Chuang PT, Hebrok M. Combined activities of hedgehog signaling inhibitors regulate pancreas development. Development 2003;130:48714879.

24. McCarthy RA, Barth JL, Chintalapudi MR, Knaak C, Argraves WS. Megalin functions as an endocytic sonic hedgehog receptor. J Biol Chem 2002;277:25660-25667.

25. McCarthy RA, Argraves WS. Megalin and the neurodevelopmental biology of sonic hedgehog and retinol. J Cell Sci 2003;116: 955-960.

26. Jobin C, Sartor RB. The IкB/NF-кB system: a key determinant of mucosal inflammation and protection. Am J Physiol Cell Physiol 2000;278:C451-C462.

27. De Santa BP, Van den Brink GR, Roberts DJ. Development and differentiation of the intestinal epithelium. Cell Mol Life Sci 2003;60:1322-1332.

28. Roberts DJ. Molecular mechanisms of development of the gastrointestinal tract. Dev Dyn 2000;219:109-120. 
29. Harmon EB, Ko AH, Kim SK. Hedgehog signaling in gastrointestinal development and disease. Curr Mol Med 2002;2:67-82.

30. Litingtung $\mathrm{Y}$, Lei L, Westphal $\mathrm{H}$, Chiang $\mathrm{C}$. Sonic hedgehog is essential to foregut development. Nat Genet 1998;20:58-61.

31. Ramalho-Santos M, Melton DA, McMahon AP. Hedgehog signals regulate multiple aspects of gastrointestinal development. Development 2000;127:2763-2772.

32. Roberts DJ, Johnson RL, Burke AC, Nelson CE, Morgan BA, Tabin C. Sonic hedgehog is an endodermal signal inducing Bmp-4 and Hox genes during induction and regionalization of the chick hindgut. Development 1995;121:3163-3174.

33. Zhang J, Rosenthal A, De Sauvage FJ, Shivdasani RA. Downregulation of hedgehog signaling is required for organogenesis of the small intestine in Xenopus. Dev Biol 2001;229:188-202.

34. Wang LC, Nassir F, Liu ZY, Ling L, Kuo F, Crowell T, Olson D, Davidson NO, Burkly LC. Disruption of hedgehog signaling reveals a novel role in intestinal morphogenesis and intestinalspecific lipid metabolism in mice. Gastroenterology 2002;122: 469-482.

35. Madison BB, Braunstein K, Kuizon E, Portman K, Qiao XT, Gumucio DL. Epithelial hedgehog signals pattern the intestinal crypt-villus axis. Development 2005;132:279-289.

36. Hebrok M, Kim SK, St. Jacques B, McMahon AP, Melton DA. Regulation of pancreas development by hedgehog signaling. Development 2000;127:4905-4913.

37. Thomas MK, Rastalsky N, Lee JH, Habener JF. Hedgehog signaling regulation of insulin production by pancreatic $\beta$ cells. Diabetes 2000;49:2039-2047.

38. Heemskerk J, DiNardo S. Drosophila hedgehog acts as a morphogen in cellular patterning. Cell 1994;76:449-460.

39. McMahon AP, Ingham PW, Tabin CJ. Developmental roles and clinical significance of hedgehog signaling. Curr Top Dev Biol 2003;53:1-114.

40. Bitgood MJ, McMahon AP. Hedgehog and Bmp genes are coexpressed at many diverse sites of cell-cell interaction in the mouse embryo. Dev Biol 1995;172:126-138.

41. Hebrok M, Kim SK, Melton DA. Notochord repression of endodermal Sonic hedgehog permits pancreas development. Genes Dev 1998;12:1705-1713.

42. Bitgood MJ, Shen L, McMahon AP. Sertoli cell signaling by Desert hedgehog regulates the male germ line. Curr Biol 1996; 6:298-304.

43. Mo R, Kim JH, Zhang J, Chiang C, Hui CC, Kim PC. Anorectal malformations caused by defects in sonic hedgehog signaling. Am J Pathol 2001;159:765-774.

44. Bose J, Grotewold L, Ruther U. Pallister-Hall syndrome phenotype in mice mutant for Gli3. Hum Mol Genet 2002;11:11291135.

45. Sukegawa A, Narita T, Kameda T, Saitoh K, Nohno T, Iba H, Yasugi S, Fukuda K. The concentric structure of the developing gut is regulated by Sonic hedgehog derived from endodermal epithelium. Development 2000;127:1971-1980.

46. Fu M, Lui VC, Sham MH, Pachnis V, Tam PK. Sonic hedgehog regulates the proliferation, differentiation, and migration of enteric neural crest cells in gut. J Cell Biol 2004;166:673-684.

47. Garcia-Barcelo MM, Lee WS, Sham MH, Lui VC, Tam PK. Is there a role for the IHH gene in Hirschsprung's disease? Neurogastroenterol Motil 2003;15:663-668.

48. Wright NA. Epithelial stem cell repertoire in the gut: clues to the origin of cell lineages, proliferative units and cancer. Int J Exp Pathol 2000;81:117-143.

49. Van Den Brink GR, Bleuming SA, Hardwick JC, Schepman BL, Offerhaus GJ, Keller JJ, Nielsen C, Gaffield W, Van Deventer SJ, Roberts DJ, Peppelenbosch MP. Indian Hedgehog is an antagonist of Wnt signaling in colonic epithelial cell differentiation. Nat Genet 2004;36:277-282.
50. Buhman KK, Wang LC, Tang Y, Swietlicki EA, Kennedy S, Xie Y, Liu ZY, Burkly LC, Levin MS, Rubin DC, Davidson NO. Inhibition of hedgehog signaling protects adult mice from diet-induced weight gain. J Nutr 2004;134:2979-2984.

51. Motoyama J, Liu J, Mo R, Ding Q, Post M, Hui CC. Essential function of Gli2 and Gli3 in the formation of lung, trachea and oesophagus. Nat Genet 1998;20:54-57.

52. Arsic D, Qi BQ, Beasley SW. Hedgehog in the human: a possible explanation for the VATER association. J Paediatr Child Health 2002;38:117-121.

53. Arsic D, Keenan J, Quan QB, Beasley S. Differences in the levels of Sonic hedgehog protein during early foregut development caused by exposure to Adriamycin give clues to the role of the Shh gene in oesophageal atresia. Pediatr Surg Int 2003;19: 463-466.

54. Ioannides AS, Henderson DJ, Spitz L, Copp AJ. Role of Sonic hedgehog in the development of the trachea and oesophagus. J Pediatr Surg 2003;38:29-36.

55. Spilde TL, Bhatia AM, Mehta S, Ostlie DJ, Hembree MJ, Preuett BL, Prasadan K, Li Z, Snyder CL, Gittes GK. Defective sonic hedgehog signaling in esophageal atresia with tracheoesophageal fistula. Surgery 2003;134:345-350.

56. Spilde T, Bhatia A, Ostlie D, Marosky J, Holcomb G III, Snyder C, Gittes G. A role for sonic hedgehog signaling in the pathogenesis of human tracheoesophageal fistula. J Pediatr Surg 2003; 38:465-468.

57. Koebbe MJ, Golden JA, Bennett G, Finnell RH, Mackler SA. Effects of prenatal cocaine exposure on embryonic expression of sonic hedgehog. Teratology 1999;59:12-19.

58. Hebrok M. Hedgehog signaling in pancreas development. Mech Dev 2003;120:45-57.

59. Apelqvist A, Ahlgren U, Edlund H. Sonic hedgehog directs specialised mesoderm differentiation in the intestine and pancreas. Curr Biol 1997;7:801-804.

60. Kim SK, Melton DA. Pancreas development is promoted by cyclopamine, a hedgehog signaling inhibitor. Proc Natl Acad Sci U S A 1998;95:13036-13041.

61. Hill D, Lebenthal E. Congenital abnormalities of the exocrine pancreas. In: Go VLW, Dimagno EP, Gardner JD, Lebenthal E, Reber HA, Scheele GA, eds. Pancreas: pathobiology, and disease. New York: Raven Press, 1993:1029-1094.

62. Van den Brink GR, Hardwick JC, Nielsen C, Xu C, Ten Kate FJ, Glickman J, Van Deventer SJ, Roberts DJ, Peppelenbosch MP. Sonic hedgehog expression correlates with fundic gland differentiation in the adult gastrointestinal tract. Gut 2002;51:628-633.

63. Dimmler A, Brabletz T, Hlubek F, Hafner M, Rau T, Kirchner T, Faller G. Transcription of sonic hedgehog, a potential factor for gastric morphogenesis and gastric mucosa maintenance, is up-regulated in acidic conditions. Lab Invest 2003;83:1829 1837.

64. Oniscu A, James RM, Morris RG, Bader S, Malcomson RD, Harrison DJ. Expression of Sonic hedgehog pathway genes is altered in colonic neoplasia. J Pathol 2004;203:909-917.

65. Birkenkamp-Demtroder K, Olesen SH, Sorensen FB, Laurberg S, Laiho P, Aaltonen LA, Orntoft TF. Differential gene expression in colon cancer of the caecum versus the sigmoid and rectosigmoid. Gut 2005;54:374-384.

66. Marigo V, Roberts DJ, Lee SM, Tsukurov O, Levi T, Gastier JM, Epstein DJ, Gilbert DJ, Copeland NG, Seidman CE. Cloning, expression, and chromosomal location of $\mathrm{SHH}$ and $\mathrm{IHH}$ : two human homologues of the Drosophila segment polarity gene hedgehog. Genomics 1995;28:44-51.

67. Zhu Y, James RM, Peter A, Lomas C, Cheung F, Harrison DJ, Bader SA. Functional Smoothened is required for expression of GLI3 in colorectal carcinoma cells. Cancer Lett 2004;207: 205-214. 
68. Van den Brink GR, Hardwick JC, Tytgat GN, Brink MA, Ten Kate FJ, Van Deventer SJ, Peppelenbosch MP. Sonic hedgehog regulates gastric gland morphogenesis in man and mouse. Gastroenterology 2001;121:317-328.

69. Kayed H, Kleeff J, Keleg S, Buchler MW, Friess H. Distribution of Indian hedgehog and its receptors patched and smoothened in human chronic pancreatitis. J Endocrinol 2003;178:467-478.

70. Kayed H, Kleeff J, Keleg S, Guo J, Ketterer K, Berberat PO, Giese $\mathrm{N}$, Esposito I, Giese T, Buchler MW, Friess H. Indian hedgehog signaling pathway: expression and regulation in pancreatic cancer. Int J Cancer 2004;110:668-676.

71. Lai K, Robertson MJ, Schaffer DV. The sonic hedgehog signaling system as a bistable genetic switch. Biophys J 2004;86:27482757.

72. Duman-Scheel M, Weng L, Xin S, Du W. Hedgehog regulates cell growth and proliferation by inducing Cyclin D and Cyclin E. Nature 2002;417:299-304.

73. Mill P, Mo R, Fu H, Grachtchouk M, Kim PC, Dlugosz AA, Hui CC. Sonic hedgehog-dependent activation of Gli2 is essential for embryonic hair follicle development. Genes Dev 2003;17:282294.

74. Barnes EA, Kong M, Ollendorff V, Donoghue DJ. Patched1 interacts with cyclin B1 to regulate cell cycle progression. EMBO J 2001;20:2214-2223.

75. Fan $\mathrm{H}$, Khavari PA. Sonic hedgehog opposes epithelial cell cycle arrest. J Cell Biol 1999;147:71-76.

76. Mehlen P, Rabizadeh S, Snipas SJ, Assa-Munt N, Salvesen GS, Bredesen DE. The DCC gene product induces apoptosis by a mechanism requiring receptor proteolysis. Nature 1998;395: 801-804.

77. Thibert C, Teillet MA, Lapointe F, Mazelin L, Le Douarin NM, Mehlen P. Inhibition of neuroepithelial patched-induced apoptosis by sonic hedgehog. Science 2003;301:843-846.

78. Mehlen P, Thibert $C$. Dependence receptors: between life and death. Cell Mol Life Sci 2004;61:1854-1866.

79. Ruiz IA, Palma V, Dahmane N. Hedgehog-Gli signalling and the growth of the brain. Nat Rev Neurosci 2002;3:24-33.

80. Altaba A, Sanchez P, Dahmane N. Gli and hedgehog in cancer: tumours, embryos and stem cells. Nat Rev Cancer 2002;2: 361-372.

81. Altaba A, Stecca B, Sanchez P. Hedgehog-Gli signaling in brain tumors: stem cells and paradevelopmental programs in cancer. Cancer Lett 2004;204:145-157.

82. Taipale J, Beachy PA. The Hedgehog and Wnt signalling pathways in cancer. Nature 2001;411:349-354.

83. Wetmore C. Sonic hedgehog in normal and neoplastic proliferation: insight gained from human tumors and animal models. Curr Opin Genet Dev 2003;13:34-42.

84. Di Magliano MP, Hebrok M. Hedgehog signalling in cancer formation and maintenance. Nature Rev Cancer 2003;3:903-911.

85. Berman DM, Karhadkar SS, Hallahan AR, Pritchard JI, Eberhart CG, Watkins DN, Chen JK, Cooper MK, Taipale J, Olson JM, Beachy PA. Medulloblastoma growth inhibition by hedgehog pathway blockade. Science 2002;297:1559-1561.

86. Berman DM, Karhadkar SS, Maitra A, Montes DO, Gerstenblith MR, Briggs K, Parker AR, Shimada Y, Eshleman JR, Watkins DN, Beachy PA. Widespread requirement for hedgehog ligand stimulation in growth of digestive tract tumours. Nature 2003;425: 846-851.

87. Mazzola CA, Pollack IF. Medulloblastoma. Curr Treat Options Neurol 2003;5:189-198.

88. Thayer SP, Di Magliano MP, Heiser PW, Nielsen CM, Roberts DJ, Lauwers GY, Qi YP, Gysin S, Fernandez-Del Castillo C, Yajnik V, Antoniu B, McMahon M, Warshaw AL, Hebrok M. Hedgehog is an early and late mediator of pancreatic cancer tumorigenesis. Nature 2003;425:851-856.
89. Watkins DN, Berman DM, Burkholder SG, Wang B, Beachy PA, Baylin SB. Hedgehog signalling within airway epithelial progenitors and in small-cell lung cancer. Nature 2003;422:313-317.

90. Hahn H, Wicking C, Zaphiropoulous PG, Gailani MR, Shanley S, Chidambaram A, Vorechovsky I, Holmberg E, Unden AB, Gillies S, Negus K, Smyth I, Pressman C, Leffell DJ, Gerrard B, Goldstein AM, Dean M, Toftgard R, Chenevix-Trench G, Wainwright B, Bale AE. Mutations of the human homolog of Drosophila patched in the nevoid basal cell carcinoma syndrome. Cell 1996;85:841-851.

91. Hahn H, Wojnowski L, Zimmer AM, Hall J, Miller G, Zimmer A. Rhabdomyosarcomas and radiation hypersensitivity in a mouse model of Gorlin syndrome. Nat Med 1998;4:619-622.

92. Kappler R, Calzada-Wack J, Schnitzbauer U, Koleva M, Herwig A, Piontek G, Graedler F, Adamski J, Heinzmann U, Schlegel J, Hemmerlein B, Quintanilla-Martinez L, Hahn H. Molecular characterization of Patched-associated rhabdomyosarcoma. J Pathol 2003;200:348-356.

93. Aboulkassim TO, LaRue H, Lemieux P, Rousseau F, Fradet $Y$. Alteration of the PATCHED locus in superficial bladder cancer. Oncogene 2003;22:2967-2971.

94. Maesawa C, Tamura G, Iwaya T, Ogasawara S, Ishida K, Sato N, Nishizuka S, Suzuki Y, Ikeda K, Aoki K, Saito K, Satodate R. Mutations in the human homologue of the Drosophila patched gene in esophageal squamous cell carcinoma. Genes Chromosomes Cancer 1998;21:276-279.

95. Reifenberger J, Wolter M, Weber RG, Megahed M, Ruzicka T, Lichter P, Reifenberger G. Missense mutations in $\mathrm{SMOH}$ in sporadic basal cell carcinomas of the skin and primitive neuroectodermal tumors of the central nervous system. Cancer Res 1998;58:1798-1803.

96. Taylor MD, Liu L, Raffel C, Hui CC, Mainprize TG, Zhang X, Agatep R, Chiappa S, Gao L, Lowrance A, Hao A, Goldstein AM, Stavrou T, Scherer SW, Dura WT, Wainwright B, Squire JA, Rutka JT, Hogg D. Mutations in SUFU predispose to medulloblastoma. Nat Genet 2002;31:306-310.

97. Kinzler KW, Bigner SH, Bigner DD, Trent JM, Law ML, O'Brien SJ, Wong AJ, Vogelstein B. Identification of an amplified, highly expressed gene in a human glioma. Science 1987;236:70-73.

98. Karhadkar SS, Bova GS, Abdallah N, Dhara S, Gardner D, Maitra A, Isaacs JT, Berman DM, Beachy PA. Hedgehog signalling in prostate regeneration, neoplasia and metastasis. Nature 2004; 431:707-712.

99. Bardeesy N, DePinho RA. Pancreatic cancer biology and genetics. Nat Rev Cancer 2002;2:897-909.

100. Day JD, Digiuseppe JA, Yeo C, Lai-Goldman M, Anderson SM, Goodman SN, Kern SE, Hruban RH. Immunohistochemical evaluation of HER-2/neu expression in pancreatic adenocarcinoma and pancreatic intraepithelial neoplasms. Hum Pathol 1996; 27:119-124.

101. Klimstra DS, Longnecker DS. K-ras mutations in pancreatic ductal proliferative lesions. Am J Pathol 1994;145:1547-1550.

102. Eberle MA, Pfutzer R, Pogue-Geile KL, Bronner MP, Crispin D, Kimmey MB, Duerr RH, Kruglyak L, Whitcomb DC, Brentnall TA. A new susceptibility locus for autosomal dominant pancreatic cancer maps to chromosome 4q32-34. Am J Hum Genet 2002; 70:1044-1048.

103. Qualtrough D, Buda A, Gaffield W, Williams AC, Paraskeva C. Hedgehog signalling in colorectal tumour cells: induction of apoptosis with cyclopamine treatment. Int J Cancer 2004;110: 831-837.

104. Watt FM. Unexpected Hedgehog-Wnt interactions in epithelial differentiation. Trends Mol Med 2004;10:577-580.

105. Weiner HL, Bakst R, Hurlbert MS, Ruggiero J, Ahn E, Lee WS, Stephen D, Zagzag D, Joyner AL, Turnbull DH. Induction of medulloblastomas in mice by sonic hedgehog, independent of Gli1. Cancer Res 2002;62:6385-6389. 
106. Xie K, Abbruzzese JL. Developmental biology informs cancer: the emerging role of the hedgehog signaling pathway in upper gastrointestinal cancers. Cancer Cell 2003;4:245-247.

107. Pola R, Ling LE, Aprahamian TR, Barban E, Bosch-Marce M, Curry C, Corbley M, Kearney M, Isner JM, Losordo DW. Postnatal recapitulation of embryonic hedgehog pathway in response to skeletal muscle ischemia. Circulation 2003;108:479-485.

108. Miyaji T, Nakase T, Iwasaki M, Kuriyama K, Tamai N, Higuchi C, Myoui A, Tomita T, Yoshikawa H. Expression and distribution of transcripts for sonic hedgehog in the early phase of fracture repair. Histochem Cell Biol 2003;119:233-237.

109. Stewart GA, Hoyne GF, Ahmad SA, Jarman E, Wallace WA, Harrison DJ, Haslett C, Lamb JR, Howie SE. Expression of the developmental Sonic hedgehog (Shh) signalling pathway is upregulated in chronic lung fibrosis and the Shh receptor patched 1 is present in circulating T lymphocytes. J Pathol 2003;199: $488-495$.

110. Oswari J, Matthay MA, Margulies SS. Keratinocyte growth factor reduces alveolar epithelial susceptibility to in vitro mechanical deformation. Am J Physiol Lung Cell Mol Physiol 2001;281: L1068-L1077.

111. Upadhyay D, Bundesmann M, Panduri V, Correa-Meyer E, Kamp DW. Fibroblast growth factor-10 attenuates $\mathrm{H}_{2} \mathrm{O}_{2}$-induced alveolar epithelial cell DNA damage: role of MAPK activation and DNA repair. Am J Respir Cell Mol Biol 2004;31:107-113.

112. Lowrey JA, Stewart GA, Lindey S, Hoyne GF, Dallman MJ, Howie $\mathrm{SE}$, Lamb JR. Sonic hedgehog promotes cell cycle progression in activated peripheral CD4(+) T lymphocytes. J Immunol 2002; 169:1869-1875.

113. Stewart GA, Lowrey JA, Wakelin SJ, Fitch PM, Lindey S, Dallman MJ, Lamb JR, Howie SE. Sonic hedgehog signaling modulates activation of and cytokine production by human peripheral CD4+ T cells. J Immunol 2002;169:5451-5457.

114. Benson RA, Lowrey JA, Lamb JR, Howie SE. The Notch and Sonic hedgehog signalling pathways in immunity. Mol Immunol 2004;41:715-725.
115. Beachy PA, Karhadkar SS, Berman DM. Mending and malig nancy. Nature 2004;431:402.

116. Kalderon D. Hedgehog signaling: costal-2 bridges the transduction gap. Curr Biol 2004;14:R67-R69.

117. Ericson J, Morton S, Kawakami A, Roelink H, Jessell TM. Two critical periods of Sonic hedgehog signaling required for the specification of motor neuron identity. Cell 1996;87:661-673.

118. Cooper MK, Porter JA, Young KE, Beachy PA. Teratogen-mediated inhibition of target tissue response to Shh signaling. Science 1998;280:1603-1607.

119. Incardona JP, Gaffield W, Kapur RP, Roelink H. The teratogenic Veratrum alkaloid cyclopamine inhibits sonic hedgehog signal transduction. Development 1998;125:3553-3562.

120. Chen JK, Taipale J, Cooper MK, Beachy PA. Inhibition of Hedgehog signaling by direct binding of cyclopamine to smoothened. Genes Dev 2002;16:2743-2748.

121. Keeler RF, Binns W. Teratogenic compounds of Veratrum californicum (Durand). V. Comparison of cyclopian effects of steroidal alkaloids from the plant and structurally related compounds from other sources. Teratology 1968;1:5-10.

122. Karlstrom RO, Tyurina OV, Kawakami A, Nishioka N, Talbot WS, Sasaki H, Schier AF. Genetic analysis of zebra fish gli1 and gli2 reveals divergent requirements for gli genes in vertebrate development. Development 2003;130:1549-1564.

123. Goodrich LV, Milenkovic L, Higgins KM, Scott MP. Altered neural cell fates and medulloblastoma in mouse patched mutants. Science 1997;277:1109-1113.

124. Park HL, Bai C, Platt KA, Matise MP, Beeghly A, Hui CC, Nakashima M, Joyner AL. Mouse Gli1 mutant are viable but have defects in SHH signaling in combination with a Gli2 mutation. Development 2000;127:1593-1605.

Received November 16, 2005. Accepted April 27, 2005.

Address requests for reprints to: Charlie Lees, MD, Gastrointestinal Unit, Western General Hospital, Edinburgh EH4 2XU, United Kingdom. e-mail: charlie.lees@ed.ac.uk; fax: (44) 01316511085. 